\title{
Når er et samtykke frivillig?
}

I 1993 ga en dødsdømt fange samtykke til at hans kropp kunne brukes til forskning etter at han var henrettet. Kroppen ble nedfryst og skåret i millimetertykke skiver og dannet grunnlaget for «The Visible Human Project». I forbindelse med at datasettet ble vurdert tatt $\mathrm{i}$ bruk i Norge, ble det reist spørsmål om fangens samtykke egentlig kunne sies å være frivillig. Rådet for legeetikk uttalte om dette prosjektet at en beslutning kan anses som frivillig hvis «den det angår (ikke) har vært utsatt for noen form for press» (1). Som belegg ble det vist til at fangen ikke selv hadde hatt noe å vinne på å gi sitt samtykke.

I 2008 ble det fremmet sterk kritikk mot deler av rusmiddelforskningen. En del av kritikken gikk ut på at «prinsippet om frivillighet brytes» ved at rusmiddelbrukere lokkes til å delta i forskning ved at de får tilgang til et helsetjenestetilbud de ellers ikke ville ha fătt (2).

Det synes klart at det skjer en utvikling mot betaling til deltakere i forskning - utover dekning av utgifter. De grunnene som oftest oppgis er at det er nødvendig både for å få rekruttert et tilstrekkelig antall personer og for at de skal fullføre studien. Det er ulike syn på om økonomiske incentiver bør tillates og $-\mathrm{i}$ tilfelle ja $-\mathrm{i}$ hvilken form og i hvilket omfang.

De aller færreste internasjonale retningslinjer gir noen veiledning i forhold til disse spørsmålene. I alle er frivillighet satt som en nødvendig betingelse for å sikre at deltakerne ikke skal tvinges eller føle seg presset. Det er lett å enes om at ingen skal utsettes for tvang eller press for å delta i forskning. De vanskelige spørsmålene er knyttet til om det er berettiget å påvirke for å motivere til deltakelse, kanskje spesielt gjennom å fremholde fordeler som kan ha betydning for den enkelte. Spørsmålet i alle disse tilfellene er om en viss grad av påvirkning er tillatelig eller ikke. Det er vel også muligens for naivt å tro eller kreve at deltakelse skal vær helt frivillig. Som mye annet kommer også frivillighet i grader. Vi tar valg som er mer eller mindre frivillige. Det er mange faktorer som kan redusere graden av frivillighet. Det vanskelige spørsmålet er hvor grensen går for at et samtykke kan sies å være frivillig.

Det er kun de etiske retningslinjene til Council of International Organizations of Medical Sciences (CIOMS) (guideline 7) (3) og Europarådets tilleggsprotokoll til konvensjonen om menneskerettigheter og biomedisin om biomedisinsk forskning (artikkel 12) (4) som erkjenner at påvirkning er legitimt i forskning. Spørsmålet er om påvirkningen er rimelig eller urimelig. I CIOMS-retningslinjene nevnes spesielt at betalingen ikke skal være så stor at det i seg selv er avgjørende for deltakelse, men at det kan gis en godtgjørelse for å kompensere for medgått tid og uleilighet. Det bemerkes også at tilbudet om tilgang til behandling ikke må være så omfattende at det på en urimelig måte påvirker mennesker til å delta i forskning i strid med deres egentlige mening. Om betaling sies det spesielt at det ikke er mulig å sette noen spesielle beløpsgrenser, hva som er rimelig må avgjøres «i lys av vedkommende kulturs og befolknings tradisjoner» (3).

Fra de prosjekter vi har nevnt er det opplagt at et menneskes livssituasjon - og sårbarhet - kan være en viktig faktor som reduserer frivilligheten. Tilleggsprotokollen legger vekt på at «sårbare og avhengige» skal vies «særlig oppmerksomhet» (4). Én måte å lese det på er at jo mer man trenger de fordeler man tilbys - av mangel på andre alternativer - desto mindre frivillig blir valget. Likevel er det viktig at forskere og komiteer ikke fratar dem som lever i sårbare situasjoner evne og mulighet til å foreta frivillige valg - det er jo en måte å umyndiggjøre dem på. Sårbarhet i seg selv er ikke noe kriterium for at påvirkning må anses som urimelig. Selv med manglende eller få akseptable alternativer kan et samtykke være i overensstemmelse med de verdier personen selv ønsker å stå for og realisere. Da må vi kunne akseptere at beslutningen er tilstrekkelig frivillig, selv om den kan være tatt i situasjoner med betydelige begrensninger. Det gjelder den dødsdømte fangen så vel som rusmiddelbrukeren.

I forbindelse med krav til «særlig oppmerksomhet» er det drøftet en rekke mulige forsiktighetsregler, som for eksempel bruk av en støtteperson eller innhenting av alternativ informasjon. Slike forsiktighetsregler har den svakhet at det er andre enn de sårbare som skal bestemme om deres valg er tilstrekkelig frivillig. Kanskje de trenger mindre paternalistisk beskyttelse enn vi er vant med å tro. Noen empiriske undersøkelser viser at pasienter er motivert til å delta fordi det kan gi direkte fordeler hva angår deres egen helse, men også fordi det kan bidra til å hjelpe andre og til økt kunnskap $(5,6)$. Betaling kan være en tilleggsmotivasjon for å delta, men langt fra avgjørende hvis betalingen er moderat og standardisert (7).

Å påvirke til deltakelse i forskning er legitimt. Det kan ikke sies noe helt bestemt om hvor grensen går for når påvirkningen må regnes som urimelig. Det avgjøres av svært mange faktorer, avhengig av prosjekt og deltakere. Den nasjonale forskningsetiske komité for medisin og helsefag har som mål å fremlegge en veiledning om betaling til deltakere i forskning i løpet av 2009. Komiteen tar gjerne imot synspunkter og eksempler fra forskere og forskningsmiljøer.

\section{Knut W. Ruyter}

knut.ruyter@etikkom.no

Knut W. Ruyter (f. 1955) er dr philos, sekretariatsleder for Den nasjonale forskningsetiske komité for medisin og helsefag og professor ved Det teologiske fakultet, Universitetet i Oslo.

\section{Oppgitte interessekonflikter: Ingen}

\section{Litteratur}

Markestad T. Bruk av datasettet «The Visible Human Project» i forskning. Tidsskr Nor Legeforen 2009; 129: 529-30.

2. Aale PK. Kan ha brutt menneskerettighetene. Aftenposten 23.6.2008.

3. CIOMS. Ethical guidelines for biomedical research involving human subject. www.cioms.ch/frame guidelines nov 2002.htm (10.2.2009).

4. Additional protocol to the convention on human rights and biomedicine, concerning biomedical research. http://conventions.coe.int/Treaty/EN/Treaties/Html/ 195.htm (11.2.2009).

5. Halpern SD, Karlawish JH, Casarett D et al. Hypertensive patients' willingness to participate in placebo-controlled trials: implications for recruitment efficiency. Am Heart J 2003; 146: 944-6.

6. Nurgat ZA, Craig W, Campbell NC et al. Patient motivations surrounding participation in phase I and phase II clinical trials of cancer chemotherapy. Br J Cancer 2005; 92: 1001-5.

7. Ballantyne A. Benefits to research subjects in international trials: do they reduce exploitation or increase undue inducement? Dev World Bioeth 2008; 8: $178-91$ 